日消外会誌 $13(7): 856 \sim 862,1980$ 年

\title{
脻切除量と腪内分泌機能の臨床研究
}

\author{
金沢大学第 2 外科 \\ 三 輪 晃一米村豊 \\ 萩 野 茂 宮 崎逸 夫
}

\section{A CLINICAL STUDY ON THE ENDOCRINE FUNCTION OF THE PANCREAS AFTER PARIAL PANCREATECTOMY}

\section{Koichi MIWA, Yutaka YONEMURA, Shigeru HAGINO and Itsuo MIYAZAKI}

2nd Surgery, School of Medicine, Kanazawa University

ヒトに括ける膵内分泌機能よりみた塍切除量の限界を, 胃全摘膵尾側合併切除, 膵十二指腸切除, 膵全 摘. 胃全摘の51例で, 経静脈的糖負荷試験，インスリン,グルカゴン分泌能の面より検討を加えた.

胃全摘膵尾側合併切除42例では，膆切除量汇対応してインスリン分泌能の著しい低下がみられ，糖尿病 の発生は膵切離腺が腹腔動脈直下（50\%切除）の25例では認めなかったが，門脈直前（65\%切除）の17例 では3 例 $(18 \%)$ に Sandmeyer 型糖尿病が発生した。

膵十二指腸切除の腹腔動脈直下膵切離 (50\%切除) の 7 例では，糖尿病の発生をみなかった.

3 例の Sandmeyer 型桾尿病は 6 カ月〜 1 年後に発生し，インスリン分泌能は全く欠如していたが，グ ルカゴン分泌能はよく保持されていた。

索引用浯 : 膵切除量, Sandmeyer 型糖尿病,インスリン,グルカゴン, 膆全摘

はじめに

膵切除は膵癌を主とする膵疾患のほかに本邦では胃癌 根治手術の合併切除として行われることも多い，対象疾 患の多くは癌で，手術の根治性を求めて睟切除範囲は次 第に広くなり，膵全摘も積極的に行われる䞻勢にある。

こうした膵大量切除・膵全摘に伴う膵内外分泌機能の低 下・脱落はインスリン・パンクレアチン投与によりある 程度補償しうるが，内分泌面では血糖値の変動が激し く，容易に低血糖に陥入り，その管理は難渋することも しばしばである。また Sandmeyer 型糖尿病と呼ばれる膆 切除後一定期間経過後に発生する糖尿病も問題となる。

膵切除後のかかる糖代謝の病態の報告の多くは動物実 験によるもので，七トの切除限界は明確でない。

筆者らは，胃全摘・脺尾側合併切除例，膵十二指腸切 除例，膵全摘・胃全摘例を対象に，糖処理能，インスリ ン分泌能，グルカゴン分泌能を検索し，膵切除後糖代謝 の病態を, 切除量, 術式, 切除後日数などより検討を加 えたので報告する.
1. 膵切離線と膵切除量の関保の吟味

膡疾患，糖㽷病を伴わない剖検例の膵を摘出し， $10 \%$ ホルマリンで約 2 時間固定後, 臨床的に切離線となる門 脈直前・腹腔動脈直下で切離し, 各々の重量を湘定, 膵 全重量に対する割合を算出した.

検索症例数は16で, 勝全重量は26〜113g, 平均 $59 \mathrm{~g}$, 重 量比では Mean士S.D. で，門脈直前切離で脺尾側65士 $9 \%$, 膵頭側 $35 \pm 6 \%$, 腹腔動脈值下切離で膵尾側 $49 \pm$ $4 \%$ ，膵頭側 $51 \pm 5 \%$ であった（図 1).この成績は佐 藤りによる Haus-Gürgen Peiper の報告に一致する.

2. 膵切除後の膵内分泌機能

1）対象拈よび検查法

胃癌術前16例を対照とし, 胃癌胃全摘膵非切除 9 例, 同脺尾側 $65 \%$ 切除17例，同膵尾側 $50 \%$ 切除 25 例，また脺 頭領域癌 - 胃癌 - 胆石症に上る脺十二指腸切除膵頭側50 $\%$ 切除 7 例, 膵癌 - 残胃再発癌の膵全摘・胃全摘 2 例を 検索対象としたそれぞれの平均年龄は57歳，62歳，55 歳，59歳，57歳 55歳であった. 対象は全て術前糖尿病 
图 1 膵切離線と切除量剖検 16 例

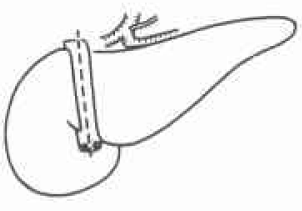

$35 \pm 6 \% \quad 65 \pm 9 \%$

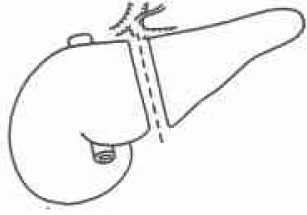

$51 \pm 5 \% \quad 49 \pm 4 \%$
がなく，切除膆のヘマトキシリン，エオジン染色による 組織学的検索で正常脺と診断されたもので, 癌再発の認 められないるのである.

経静脈的ブドウ糖負荷試験 (IV-GTT) は早朝空腹時 にブドゥ糖 $0.5 \mathrm{~g} / \mathrm{kg}$ b.w. を 2 分間で静注，注入前，注入 後 $3 ， 5 ， 10 ， 20 ， 30 ， 40,60$ 分後に採血乙，血糖值， インスリン值（IRI），グルカゴン值（IRG）を测定し た.

経静脈的アルギニン負荷試験（ATT）は，早朝空腹時

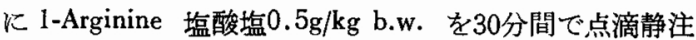
乙, 注入前, 開始後 $5,10,15,20,30,45,60$ 分に採 血し，血糖値，IRG を測定した.

血清の保存は血液 $1 \mathrm{mI}$ につき EDTA $2 \mathrm{Na} \quad 1.2 \mathrm{mg}$. Trasyrol 500単位を加光， $4^{\circ} \mathrm{C} ， 3,000 \mathrm{rpm} ， 15$ 分間遠心 L, 血清を分離, $-80^{\circ} \mathrm{C}$ に凍結保存した.

血糖值の測定は glucose-oxidase ${ }^{2)}$ により，IRI は Sephadex 固相法による radioimmunoassay) で， IRG は膵グルカゴン特異抗体とされる $30 \mathrm{~K}$ を用い， dextrancharcoal 法による radimmunoassay ${ }^{4)}$ で測定した。

糖処理系数（K値）は IV-GTT の血糖下降カーブを semilogarithmic paper にあらわし，ブドウ糖負荷後10分 時の血糖値の $1 / 2$ になる時間 $\mathrm{t} 1 / 2$ を求め, $\mathbf{K}=\frac{0.693}{\mathrm{t} 1 / 2} \times$ 100の式より算出した ${ }^{5)}$ 。な Insulinogenic Index (I.I.) は糖負荷後 3 分のIRI 増加量を血糖増加量で除した 值 $(\mu \mathrm{u} \cdot \mathrm{dl} / \mathrm{ml} \cdot \mathrm{mg})$ であらわし Total Insulinogenic Index (T.I.I.) はブドウ糖負荷前值より増加した60分間 の IRI の総面積を血糖増加総面積で除した值 $(\mu \mathrm{u} \cdot \mathrm{d} \mathrm{d} /$ $\mathrm{ml} \cdot \mathrm{mg}$ ) であらわした IRG はATTの Arginine 負 荷前値より増加した60分間の $\mathrm{IRG}$ 総面積 $(\mathrm{ng} \cdot \mathrm{min} / \mathrm{ml}$ ) とした.

2）同一症例にお污る胃癌胃全摘膆尾側切除後の膵内 分泌機能の経時的変化

膵尾側 $65 \%$ 切除 8 例, $50 \%$ 切除 6 例飞ついて, 術前, 術後 $4 \sim 6$ 週，1 年で検索した.

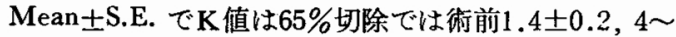

6 週0.7士0.2，1 年0.7士0.1，50\%切除では術前 $1.1 \pm$

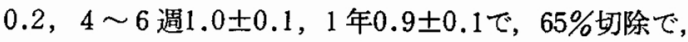
より著明な低下がみられ，両群とも経時的な改善はみら れない。

I.I. は65\%切除では術前0.41士0.14，4〜6 週0.07士 $0.02,1$ 年0.06士0.01，50\%切除では術前0.20士0.04,

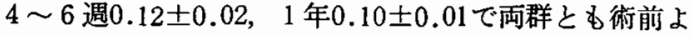
り明らかな低値をとり $(\mathrm{p}<0.01) ， 65 \%$ 切除ではより著 明な低下 $(p<0.05)$ がみられ，経過とともに改善する 傾向はみられない。

T.I.I. は65\%切除では術前 $0.24 \pm 0.04,4 \sim 6$ 週0.04 $\pm 0.01,1$ 年 $0.03 \pm 0.01,50 \%$ 切除では術前0.17士0.03,

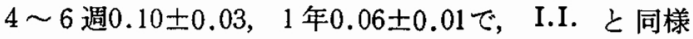
両群とも低下し，かつ65\%切除で有意の低下を示した $(\mathrm{p}<0.05)$.

$\Sigma \Delta$ IRG では65\%切除で術前14.6士4.1，4〜6週4.3 $\pm 0.8,1$ 年 $9.6 \pm 2.7,50 \%$ 切除では術前 $8.5 \pm 2.8,4$

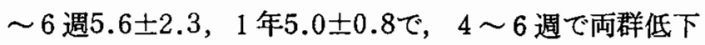
するも 1 年後には改善傾向が少られた（図2).

以上をまとめると, 脺切除後糖処理能, インスリン分 泌能は切除量に対応して低下し, 経過を追っても回復し ないのに対し，グルカゴン分泌能は術後一時低下する む， 1 年後には回復傾向があることが示された。

図 2 同一症例における胃癌胃全摘膵尾側切除後の 膵内分泌機能の経時的変化

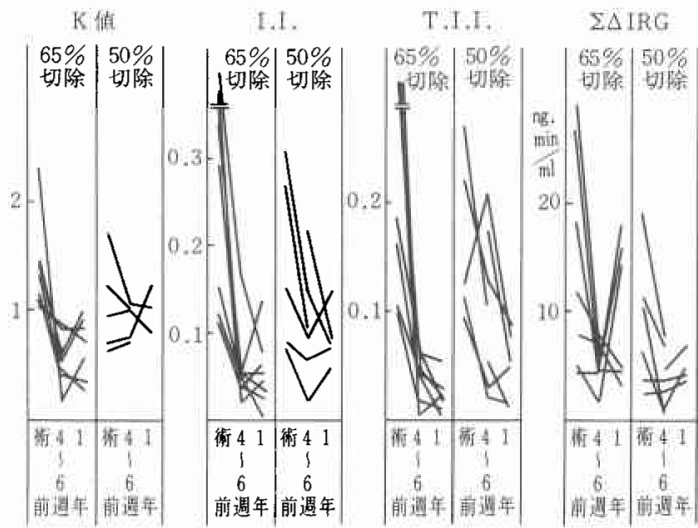

3）胃癌胃全摘膵尾側切除後の長期の膵内分泌機能 術後長期の膵内分泌機能の変化を推測するため, 症例 を $4 \sim 6$ 週，1〜2 年， $2 \sim 5$ 年に別け検討した.

Mean \pm S.E. で，K值は65\%切除で $4 \sim 6$ 週（8例） で0.7士0.2, $1 \sim 2$ 年 (11例) $0.8 \pm 9.1 ， 2 \sim 5$ 年（ 4 
例) $0.7 \pm 0.1,50 \%$ 切除で $4 \sim 6$ 週 ( 7 例) $1.1 \pm 0.1$, $1 \sim 2$ 年 (11例) $1.1 \pm 0.1,2 \sim 5$ 年 ( 7 例) $0.9 \pm 0.1$ で術前（16例）の1.3土0.1K比乙両群とも有意に低下し $(\mathrm{p}<0.01), 1$ 年以降でも改善がみられなかった。

I.I. は65\%切除で $4 \sim 6$ 週0.07士0.02, $1 \sim 2$ 年0.08 $\pm 0.03,2 \sim 5$ 年0.06士0.02, $50 \%$ 切除で $4 \sim 6$ 週0.12

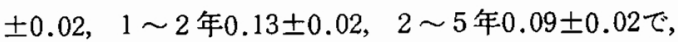
術前0.34 0.08 に対し術後は切除量に対応し有意に低下 $(p<0.01), 1$ 年以降でも改善はみられなかった。

T.I.I. は65\%切除では $4 \sim 6$ 週で0.04士0.01, $1 \sim 2$

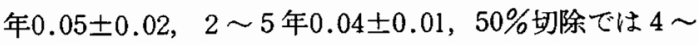
6 週0.11士0.03, $1 \sim 2$ 年0.07士0.04, $2 \sim 5$ 年0.06士 0.01 で，術前 $0.22 \pm 0.02$ に対し術後低下がみられ，低下 の程度は65\%切除群で高度で改善の傾向はみられなかっ た.

$\Sigma \Delta$ IRG は65\%切除で $4 \sim 6$ 週4.3土0.7，1〜2年8.7 $\pm 2.0,2 \sim 5$ 年7.3土1.9, $50 \%$ 切除で 4 〜 週5.7士 $2.3,1 \sim 2$ 年 $5.2 \pm 0.8,2 \sim 5$ 年 $5.9 \pm 1.0$ で, 術前 11.0 土2.5に比し $4 \sim 6$ 週で両群とも低下する $(\mathrm{p}<0.05)$ む，1年以降では改善する傾向を認めた（図3).

図 3 胃癌胃全摘膵尾側切除後の長期の膀内分泌機 能

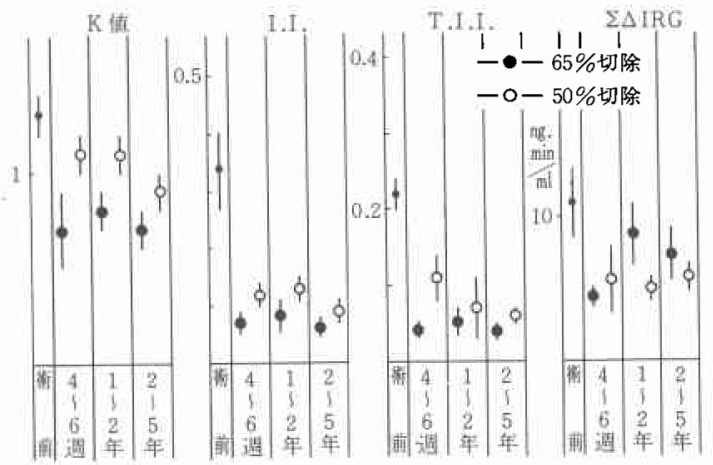

以上をまとめると, 膵切除後 $4 \sim 6$ 週では糖処理能・ インスリン分泌能・グルカゴン分泌能は低下する. $5 ち$ 糖処理能・インスリン分泌能は 1 年以降す低下したまま で全く改善しないのに対し，グルカゴン分泌能は改善す る傾向が認められる. また 1 年以降では糖処理能，イン スリン分泌能・グルカゴン分泌能のいつれれの值も一定と なることが明らかとなった。

4）脺切除後 1 年以上経過例の脺内分泌機能

膵切除後 1 年以上経過すると脺内分泌機能が一定とな ることより，1 年以上経過例について検討を加えた，術
式および症例数は胃全摘膵非切除 9 例，同膵尾側 $65 \%$ 切 除17例，同脺尾側 $50 \%$ 切除 25 例，搭十二指腸膡頭側 $50 \%$ 切除 7 例である.

Mean \pm S.E. で， 空腹時 血糖値 は胃全摘膵非切除84 $\pm 2 \mathrm{mg} / \mathrm{dI}$ ，同膵尾側 $65 \%$ 切除 $78 \pm 4 \mathrm{mg} / \mathrm{dl}$, 同腈尾側 $50 \%$ 切除 $82 \pm 4 \mathrm{mg} / \mathrm{dl}$, 膵十二指腸切除膰頭側 $50 \%$ 切除 $87 \pm 3$ $\mathrm{mg} / \mathrm{dl}$ で術前 $87 \pm 2 \mathrm{mg} / \mathrm{dl}$ に比し差はみられなかった。

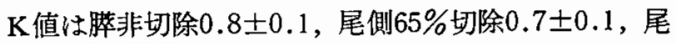
側 $50 \%$ 切除 $1.0 \pm 0.1$ ，頭側 $50 \%$ 切除 $0.9 \pm 0.2 て ゙$ 術前 1.3 \pm 0.1 にくらべ有意に各群とも低下した $(\mathrm{p}<0.05)$.

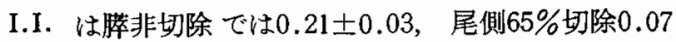
\pm 0.02 , 尾側 $50 \%$ 切除 $0.12 \pm 0.02$, 頭側 $50 \%$ 切除 $0.01 \pm$ 0.03 と術前0.34 00.07 より有意に低下した $(\mathrm{p}<0.01)$.

T.I.I. では脺非切除0.14士0.03, 尾側 $65 \%$ 切除0.04士 0.01 , 尾側 $50 \%$ 切除 $0.06 \pm 0.01$, 頭側 $50 \%$ 切除 $0.07 \pm 0$. 02 で術前 $0.22 \pm 0.02$ に比し膵切除群で有意の低下を示し た $(\mathrm{p}<0.01)$.

$\Sigma \Delta$ IRG は脺非切除 $10.0 \pm 2.5$, 尾側 $65 \%$ 切除 $8.2 \pm$ 1.5 , 尾側 $50 \%$ 切除 $5.5 \pm 1.0$, 頭側 $50 \%$ 切除 $13.3 \pm 3.2 て ゙$ 術前9.3土2.5に比し膵切除群で差異を見出し難かった (図 4, 5).

以上をまとめると, 㬺切除により糖処理能・インスリ ン分泌能は切除量に対応して低下するが，グルカゴン分 泌能は術後代償される. 膵尾側 $50 \%$ 切除と膆頭側 $50 \%$ 切 除では糖処理能，インスリン分泌能・グルカゴン分泌能 に有意差はなかった. また胃全摘膵非切除でも糖処理 能・インスリン分泌能は低下することが示された。

5）荤切除後糖尿病の発生

糖尿病の発生を膵切除後 1 年以上経過例で Lundbaek の糖尿病判定基準 ${ }^{5)}$ ，すなわち $\mathrm{K}>1.1$ 正常型， $1.1>$ $\mathrm{K}>0.9$ 境界型, $0.9>\mathrm{K}$ 糖尿病型に基つくく, 糖尿病型 は膵非切除 0\% (0/9)，尾側65\%切除82\%（14/17），尾

図 4 膵切除後 1 年以上経過例の IV-GTT と IRI

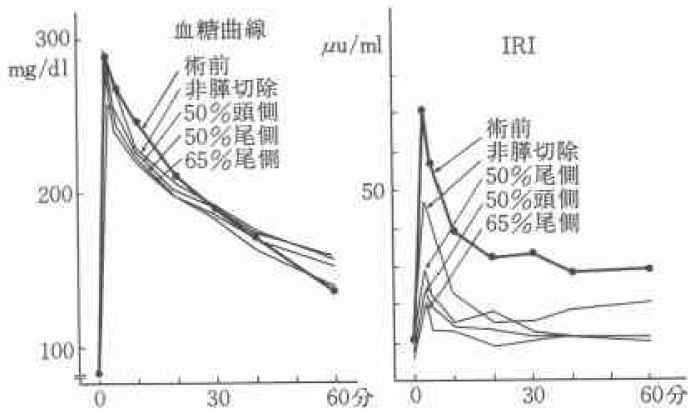


図 5 勝切除後 1 年以上経過例の ATT と IRG A T T

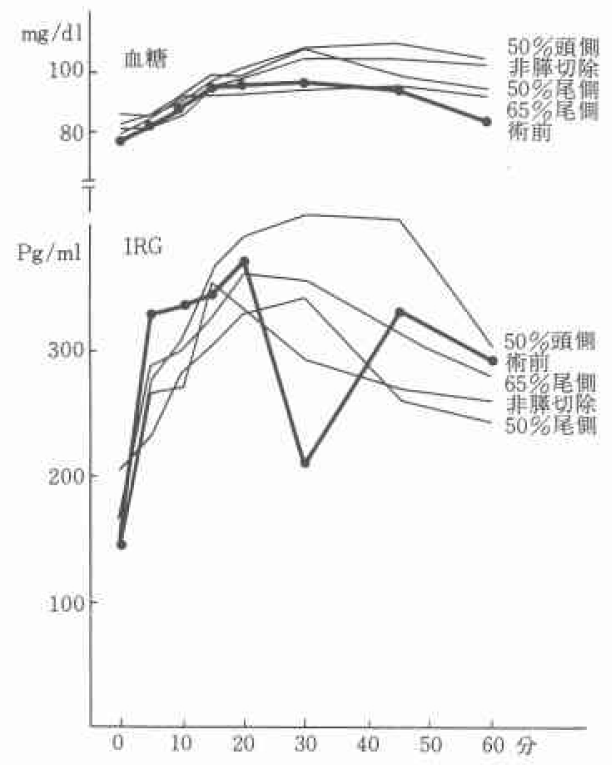

図 6 腾切除後糖尿病の発生率

\begin{tabular}{|c|c|c|c|}
\hline 基 準 & $\begin{array}{c}65 \% \\
\text { 尾側切除 }\end{array}$ & $\begin{array}{c}50 \% \\
\text { 尾側切除 }\end{array}$ & $\begin{array}{c}50 \% \\
\text { 頭側切除 }\end{array}$ \\
\hline$K<0.9$ & $82 \%(14 / 17)$ & $48 \%(12 / 25)$ & $71 \%(5 / 7)$ \\
\hline $\begin{array}{l}\text { 空腹時血糖 } \\
140 \mathrm{mg} / \mathrm{dl} \text { 以上 }\end{array}$ & $35 \%(6 / 17)$ & $0 \%(0 / 25)$ & $0 \%(0 / 7)$ \\
\hline $\begin{array}{l}\text { Sandmyer 型 } \\
\text { 糖尿病 }\end{array}$ & $18 \%(13 / 17)$ & $0 \%(0 / 25)$ & $0 \mathscr{6}(0 / 7)$ \\
\hline
\end{tabular}

側50\%切除48\%（12/25）, 頭側50\%切除71\%（5/7）飞及 られた。

空腹時血糖 $140 \mathrm{mg} / \mathrm{dl}$ 以上の顕性糖尿病は 7 例で, 全 例尾側65\%切除で，5ち 4 例は術直後より発生し，2 3 力月で改善, 残り 3 例は 6 力月 1 年後に発生し, い わゆる Sandmeyer 型糖尿病であった（図6）.

6) Sandmeyer 型糖尿病症例

65歳男性, 60 歳男性，52歳男性で，発症は 6 力月， 1 年, 1 年 1 力月後である.

代表症例として65歳男性例を詳述する. 胃癌症例で術 前K值1.1， I.I. 0.16， T.I.I. 0.16， $\Sigma \Delta$ IRG 26.6で, 手術は Appleby 法による 胃全摘・膆尾側65\%切除を施 行した. 術後 4 週ではK値0.6, I.I. 0.04, T.I.I. 0.03， $\Sigma \Delta$ IRG 4.5 之低下を認めたが，尿糖は陰性であった。 術後 6 カ月で多尿を訴兄, 検査の結果空腹時血糖は350 $\mathrm{mg} / \mathrm{dl}$ と著明飞増加し，K值0.3， I.I. 0, T.I.I. 0とイ
ンスリン分泌の欠如がみられ， $4 \Sigma$ IRG は7.9と增加し， 空腹時 IRG $440 \mathrm{pg} / \mathrm{ml}$ と高值を示した. インスリン 治療の開始とともに尿糖排出は減少し，2力月後の空腹 時血糖は $98 \mathrm{mg} / \mathrm{dl}$ と正常化し，空腹時 IRG は $168 \mathrm{pg} / \mathrm{dl}$ と低下した（図 7).

図 7 Sandmeyer 型糖尿病（65才合65\%膵切除）

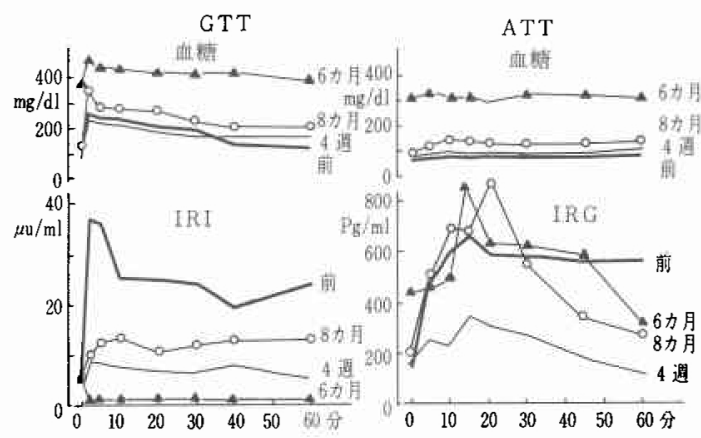

インスリン治療中止後 2 週目のK値は0.7, I.I. 0.03, T.I.I. 0.04で, 以後食飼療法で経過観察するも, 数力月 後には顕性糖㽷病の再発を来し，インスリン治療を余儀 なくされている.

7）膵全摘，胃全摘例におけるグルカゴン分泌

筆者らの IRG 測定に使用した脺グルカゴン特異抗 体は腸管グルカゴンと交叉反応することが指摘されてお

図 8 膵全摘例の ATT

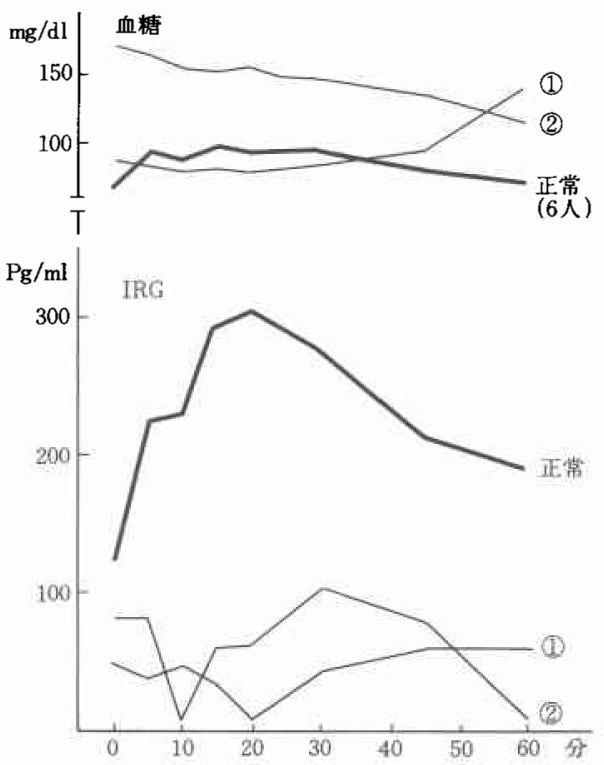


図 9 膵切除後残存膵ラ島の組織学的変化

\begin{tabular}{|c|c|c|c|c|c|c|c|}
\hline 症例 & 年 & 性 & 術後 & 膵切除量 & 脱顆粒 & 水腫様変性 & ラ島線維化 \\
\hline Y.H & 57 & 우 & $2 \mathrm{M}$ & $50 \%$ 尾切 & + & - & - \\
\hline M. K & 65 & $\delta$ & $3 Y$ & $65 \%$ 尾切 & + & + & + \\
\hline K. N. & 75 & 우 & $1 \mathrm{Y}$ & $50 \%$ 尾切 & + & - & - \\
\hline $\mathrm{K} . \mathrm{H}$ & 57 & $\delta$ & $5 \mathrm{M}$ & $65 \%$ 尾切 & + & + & - \\
\hline S.Y. & 50 & $\hat{o}$ & $3 Y$ & 50 名尾切 & - & - & - \\
\hline I . T. & 63 & $\delta$ & $5 \mathrm{D}$ & $35 \%$ 頭切 & - & - & - \\
\hline H.W. & 47 & 우 & $2 Y$ & 50 多頭切 & + & - & - \\
\hline H. K. & 51 & $\hat{\delta}$ & $10 \mathrm{M}$ & $50 \%$ 頭切 & + & - & - \\
\hline J.O & 67 & $\hat{o}$ & $2 \mathrm{M}$ & $50 \%$ 頭切 & - & - & - \\
\hline M. T. & 65 & 우 & $1 \mathrm{Y}$ & $50 \%$ 頭切 & - & - & - \\
\hline K.O. & 67 & $\hat{\delta}$ & $4 \mathrm{Y}$ & $50 \%$ 頭切 & - & - & - \\
\hline
\end{tabular}

り，ヒトにおける腸管グルカゴン分泌を䐗全摘・胃全摘 の 2 例で ATT で検索した，その結果は CRP は全く認 められすั，IRG は $\mathrm{pg} / \mathrm{ml}$ で，それぞれ前78；50,5分 $78 ; 40,10$ 分 $10 ; 50,15$ 分 $74 ; 35,20$ 分 $78 ; 10,30$ 分 $105 ； 45 ， 45$ 分 $80 ； 60$ ，60分 $10 ； 60$ で全経過にわたり低 値を示し，反応はみられなかった（図8）.

3. 剖検例での㬺切除後残存膵ラ島の組織学的変化 胃全摘脿尾例 $65 \%$ 切除 2 例, 同膵尾側 $50 \%$ 切除 3 例, 荟十二指腸切除膆頭側 $50 \%$ 切除 1 例, 同脺頭側 $35 \%$ 切除 1 例の計 11 で検索した.これら症例の術後期間は 4 年か ら5日であった。染色は Gomori の aldehyde-fuchsin に よる藤田変法6)を用いた。

その結果11例中 6 例に $\beta$ 細胞の脱顆粒, 水腫様変性, ラ島の線維化などの变化がみられた. 水腫様変性, ラ島 の線維化などの高度変化は 2 例にみられ, いつれる65\% 尾側切除で術後 5 カ月 3 年死亡例であった. しかし 細胞の形態は良く保持されていた（図9）.

\section{考察}

膵切除後の糖尿の発現形式には次の 4 型がある. 即ち

1. 脺切除後一過性の榶尿をみるも, 数週後に正常化 する型。

2. 膵切除直後は軽度であるが，数力月後に高度の糖 尿となる型

3. 膵切除直後より高度の糖尿を呈する型

4. 膆全摘により直ちに糖尿を発生する型 である。

このらち1は一過性であり遠隔時では問題とならな く, 膵切除後の糖尿病として重要なのは $2 \sim 4$ であろ.
実地臨床上，正常膵を単独に切除する機会は少なく， 脺切除単独の脺内分泌機能への影響をみた 報告は少な

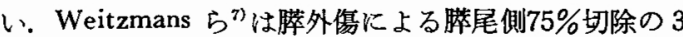
例では糖尿病を発生しなかったとし，また Norton ら は急性出血性膵炎の尾側 $85 \%$ 切除例にインスリン依存性 糖尿病発症をみたが，80\%切除以下では発症しなかった としている. また Frey ${ }^{9)}$ る慢性膵炎患者の勝切除では インスリン依存性糖尿病の発生は膵尾側80 90\%切除で $79 \% ， 40$ 80\%切除では18\%であったとし，粹尾側切除 量は $80 \%$ 以下に止めるべきとしている.

胃全摘に伴ら膵尾側切除の場合，鈴木 ${ }^{20)}$ は中結腸動脈 の膵下縁交叉部での切離，すなわち2/5〜3/5切除22例の 空腹時血糖・糖二重負荷試験による検索では, 術後 4 週で 耐糖能の低下をみるる遠隔時には回復するとし，本橋 ${ }^{11)}$ は門脈左縁切離による勝尾側 $2 / 3$ 切除を行う Appleby 手 術例で，O-GTT による血糖曲線および血中インスリン 動態を IRI で検索し，40例中 8 例 $20 \%$ に糖尿病型血糖 曲線がみられたとしている。

膵頭側切除は術式が幽門側胃部分切除・十二指腸切除 を合併する膵十二指腸切除術となるが， Miyata $5^{12)}$ ， Fish $5^{13)}$ は膆頭側1/3切除では酎糖能・インスリン分泌 能の低下を認めるものの，糖尿病の発症をみなかったと 乙, 山崎 ${ }^{14)}$ は膵頭側 $2 / 3$ 以上切除で, 空腹時血糖 $120 \mathrm{mg} / \mathrm{dl}$ 以上の症例を11例中 2 例に認めている。

筆者らは膵内分泌機能をできるだけ直接的に検索せん と,インスリン分泌検查は経静脈的糖負荷により行い, また近年測定法の確立されたグルカゴンの分泌能をも検 査した。 
まず脺非切除の胃全摘例では顕性糖尿病はみられない ものの，K值，I.I., T.I.I. の有意の低下がみられ，胃 全摘そのもので脺内分泌機能の低下を来すことが示され た.このことは前述の脺切除後の脺内分泌機能の諸家の 報告で, 脺切除単独で糖尿病を発生する切除量は80\%以 上とするのに 対し，胃全摘・胃切除を伴ら膵切除では $2 / 3$ 以上と若干少ない傾向 と一致する. 胃全摘単独であ 脺内分泌機能が低下する機序は迷走神経切断, リンパ節 廓清による自律神経切断，潜在的な癌再発の影響など 複雑な因子が関与することも考えられるが，胃全摘後の

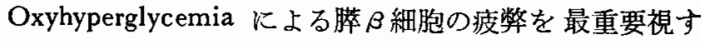
ハきであろう。

脺尾側切除を伴う胃全摘ではK值, I.I., T.I.I. いず れも低下し，胃全摘・脺非切除の I.I. : T.I.I. を100\% とすると，それぞれ65\%切除では34\%:31\%，50\%切除 では45\%：40\%と添ぼその切除量に対応した低下がみら れ，かつ経時的な回復は認められなかった. グルカゴ ン分泌能は脺切除後一担低下寸るも，65\%・50\%いずれ む1 年後には回復傾向がみられ，膵全摘・胃全摘例では 30Kに反応するグルカゴン分泌がみられないことより， 残存脺のグルカゴン分泌能が回復するわのと推則され た。

Sandmeyer 型糖尿病は65\%切除の 3 例にみられたが, これらではインスリン分泌が全くみられず，逆にグルカ ゴン分泌は過剰とも思える值を示して扣り，両ホルモ ン分泌に解離がみられることが特徽的であった。 また Sandmeyer 型糖㽷病は治療により可逆的であり，インス リン分泌能が回復することも明らかとなった.

糖尿病の発生は Lundbaek の基準で，65\%切除 $82 \%$, $50 \%$ 切除 $48 \%$ で, Sandmeyer 型桾尿病でみると65\%切除 $18 \% ， 50 \%$ 切除 0\%の発生率 となった. $65 \%$ 切除の成 績は本橋 ${ }^{11}$ の Appleby 手術40例中 8 例 $20 \%$ の糖尿病型 GTT 曲線をみたとする報告と一致するるのであった。

膵頭側 $50 \%$ 切除では脺尾側 $50 \%$ 切除と変らぬ膵内分泌 機能の成績が得られた. Wittingen ら 分布を組織学的に検索し, 頭部・体部・尾部・釣状突起 では尾部にラ島が有意に多いとし，同量の膵切除では尾 側切除より頭側切除の方が糖尿病の発生が少なかららと 述べているが，自験例では膵頭側 $50 \%$ 以上の切除例がな いので言及でさない。

$$
\text { まとめ }
$$

膵切除量と膵内分泌機能の 関係を胃全摘, 塍非切除 例，同 - 脺尾側合併切除例，膵十二指腸切除例，膵全
摘・胃全摘例で, 耐糖能・インスリン分泌能・グルカゴ ン分泌能より検討した.

膵切離部位と脺切除量の関係を剖検例で検索したとこ ろ，腹腔動脈直下で頭側・尾側 $50 \%$, 門脈直前切離で頭 側 $35 \%$ ，尾側 $65 \%$ であった。

胃全摘単独でも膵内分泌機能は低下乙, 膵尾側合併切 除例ではインスリン分泌は切除量に対応した低下がみら れ, かつ経過を追っても回復しないのに対し，グルカゴ ン分泌能は術後一過性に低下するも，1 年以降で改善傾 向がみられる. Sandmeyer 型糖尿病の発生は65\%切除例 で18\%に認めたが，50\%切除例では未だみられていな W.

頭側 $50 \%$ 切除例の脾内分泌機能は尾側 $50 \%$ 切除例之差 異はなく，糖尿病の発生をみなかった。

以上の成績より, 胃切除を伴う脺切除は尾側, 頭側と も腹腔動脈直下の切離線まで安全で，これを超えた場合 は Sandmeyer 型粘㽷病の発生を考虑に入れ，厳重な術 後追跡と管理が必要と考える.

\section{文献}

1) 佐藤寿雄：膵体尾部切除. 消化器外科, 2 : $131-143,1979$.

2) 馬場茂明, 奥田 清 : 血糖, 山村婎一監修, 医 化学実験講座, 第 3 巻 B, 臨床化学 II, 第 1 刷: 118-125，中山書店, 1973 .

3) 井出健彦: Sephadex 固相法によるインスリン の簡易測定 Kit (S-8530) 臨床成人病, 2 : 209-210, 1972 .

4) Unger, R.H., Eisentraut, A.M., et al.: Measurement of endogenous glucagon in plasma and the influence of glucagon antibodies and this use for radioimmunoassay for glucagon. Proc. Soc. Expel. Biol. Med., 102: 621-623, 1959.

5) Lundbaek, K.: The intravenous-glucose tolerance test. Triangle, 6: 194-198, 1964.

6) 藤田恒夫, 渡辺雪子：ランゲルハンス島のA・ B ・ D 細胞の 染色法. 臨床検查, $16: 29-32$, 1972 .

7) Weitzman, J.J. and Rothschild, P.D.: The surgical management of traumatic rupture of the pancreas due to blunt trauma. Surg. Clin. North. Amer., 48: 1347-1353, 1968.

8) Norton, L. and Eisenman, B.: Near total pancreatectomy for hemorrhagic pancreatitis. Amer. J. Surg., 127: 191-195, 1974.

9) Frey, C.F.: Pancreatic pseudocyst, operative strategy. Ann. Surg., 188: 652-662, 1978.

10) 鈴木次郎：膵尾側合併切除飞就て.日本外科学 会雑誌, 55：836-852, 1954. 
11）本橋久彦：胃全摘後の糖代謝について. 横浜医 学, 27:87-97, 1976.

12) Miyata, M., Takao, T., et al.: An appraisal of radical pancreaticoduodenectomy based on insulin secretion. Amer. J. Surg., 133: $577-$ $581,1977$.

13) Fish, J.C., Smith, L.B., et al.: Digestive function after radical pancreatoduodenectomy.
Amer. J. Surg., 117: 40—45, 1967.

14）山绮又次郎：猝頭切除の予後ならびに術後遠隔 時の膵肝機能検查成續について.日本外科学会 雑誌, 68 : 374-394, 1967.

15) Wittingen, J. and Frey, C.F.: Islet concentration in the head, body, tail and uncinate process of the pancreas. Ann. Surg., 179: 412414, 1974. 